\title{
SOME POWERFUL TECHNIQUES FOR INTANGIBLE INCENTIVES EMPLOYEES
}

\section{Valeriy Okulich-Kazarin}

Taganrog State Teachers Training University, Department of management, Taganrog, Rostov region, Russia

\section{Olga Prichina}

Engineering-technological Academy of the Southern Federal University, Department of management, Taganrog, Rostov region, Russia

\section{Irina Stecenko}

Taganrog State Teachers Training University, Department of management, Taganrog, Rostov region, Russia

\section{(C) MESTE NGO}

JEL category: D2, D23

\begin{abstract}
We investigated the methods of increase of labor productivity. The focus was on the motivation of employees to work more and better. We have performed a study of scientific sources, modeling and testing some techniques. The orthodox view is that the managers prefer to use the material motivation of the personnel as the main tool. To the best of our knowledge there are no results in the literature regarding how to rapidly increase productivity without large investments in motivation. Literature review shows that experts in motivation support the methods of material motivation.

We found in literature that $12 \%$ of employees have money as the main motive of work only. In other words the methods of intangible incentives are important for $88 \%$ of employees.

We chose 2 powerful techniques of intangible incentives: competition and training.

Competition shows growth of the educational productivity to $28.22 \%$. It was not required expenditures of money or other resources.

The economic results of our training are the following:

- the purpose of the order was achieved as the speed and quality of work of managers grew by 57$96 \%$,

- comprehensive approach to the development of managerial skills and competencies brought additional 180 man-days,

- saving of budget staff development amounted to $\$ 30,500$ through the use of new patented technologies of training managers.
\end{abstract}

Address of the corresponding author:

That is why we suggest competition and training as Valeriy Okulich-Kazarin 玤0kvp@yandex.ru 
Keywords: labor productivity, personnel, employees, intangible incentives, methods of motivation, techniques of motivation

\section{INTRODUCTION}

Do you know why Russia lags behind Western Europe in productivity 3-4 times (Smirnov, 2011, p. 1) and growing so slowly? Because such talented scientists, as A.K. Gastev, P.M. Kergencev, A.A. Bogdanov, O.A. Ermansky were not in demand. And the Russian schools of labor organization has been replaced by an administrative management style (Smirnov, 2011, p. 1). Intergenerational continuity was broken. In Russian universities professors teach methods of work organization, which are more than 50 years. Therefore, the production managers do not have knowledge about how to increase productivity.

Consequently, many companies are not able to get the best performance from their employees. Managers use ineffective methods of control (Davenport, 2011, p. 2). Therefore, Russia has low labor productivity. The problem is the development of powerful techniques for rapid and significant growth of labor productivity.

The authors recently started a research program to find ways of additional motivating of employees. We want to help to businessmen and managers to have employees working more and better. Analytical techniques are needed that can predict the behavior of the staff in the use of intangible incentives.

Analytical techniques have been extensively applied to the study of the working conditions of the personnel, in particular with respect to efficiency of the methods of motivation. However, little research has described of practical methods of intangible incentives.

More recent research [(Cvetkov, 2008) (CenterYF, 2012) (Yandex.Direkt, Sposoby povyshenija proizvoditel'nosti truda/ Konsul'tant, 2012) (hw4, n.d.)] has occurred in the field of approaches to increasing productivity. These works show that productivity can be increased through large investments. Other authors [(Gorin, 2006) (Yandex.Direkt, Motivatsiya personala, 2012) (Kak povysit' proizvoditel'nost, 2013) (Shatova, 2014)] have found an opportunity to apply the intangible incentives.
To the best of our knowledge there are no results in the literature regarding how to rapidly increase productivity without large investments.

The aim of the present work is to analyze the effectiveness of different methods of intangible stimulation of the personnel. The assumptions (Yandex.Direkt, Motivatsiya personala, 2012) are used as a starting point.

The results of the research are encouraging. And its show that the companies can increase productivity. It must using some powerful techniques for intangible incentives of employees.

The results of the research are applied in the practice of Russian and other companies. They can be useful for companies seeking to raise labor productivity of employees. Our results are very important in the beginning of world crisis. Managers will rejoice in the results of work of employees and the success of their Company when they can learn and implement our intangible incentives techniques.

\section{LITERATURE REWIEW}

For more than 100 years researchers have been observing of labor productivity.

Frederick Winslow Taylor found that all people are divided into two classes (F.W. Taylor about the principles of scientific management, 1911). Representatives of the first class are committed to the speedy completion of the work. They do not waste time in vain and not shy away from their responsibilities. People of the second class are characterized by low productivity is the norm of work and behavior. Thus, the employee may develop from the second class to first class. Managers and businessmen should create conditions for that.

However F.W. Taylor believed that the work must be paid by results. In his study, salary is higher than more products produced worker and the more normalized work it has done (Cvetkov, 2008). Although the author proposed to determine the normal conditions for work (convenience workplace, sanitary and hygienic conditions, the continuity of the provision of raw materials, tools, 
and so on) implementation of his ideas were met with resistance from both the employees and managers.

G. Ford continued F. Taylor's ideas in the area of production organization. He formulated the main principles of organization of production and, for the first time, separated the management from the main work (Cvetkov, 2008).

In the USSR the system of F. Taylor was interpreted in the A.K. Gastev's studing as a scientific organization of labor (Smirnov, 2011).

F. Taylor's principles and approaches are quite applicable in our time. They can be used where the labour process can be dissected into several simple operations and there is no possibility to replace people with machines.

In (Center-YF, 2012, p. 2) the most important task of the enterprise is the continuous search and implementation of provisions of productivity growth.

Today Russia has the following distribution of approaches to increasing labor productivity (Center-YF, 2012, p. 12):

- improving the technical level of production (mechanization and automation of production; introduction of new types of equipment; the introduction of new technological processes, improvement of structural properties of the products; increasing the quality of raw materials and new construction materials);

- improving the organization of production and labor (improvement of standards and service areas; reduction of the number of workers that do not follow the rules; streamlining of the management structure; mechanization of accounting and computing work; change working period; increased specialization of production);

- change of the external, natural conditions (change geological conditions of extraction of coal, oil, ore, peat; change the content of useful substances);

- structural changes in production (change the weights of certain products; change the complexity of the production program; a change in the share purchase semi-finished products and components; the weight of new products).

However, performance management of employees in the work (Center-YF, 2012, p. 2) is an integrated process built on three positions:

1. performance measurement - i.e. assessment of employees.

2. employee development.

3. tangible encouragement for those who are the most effective.

You see, the algorithm of actions of managers focuses on money and other material values (№3).

It was speculated by author (Yandex.Direkt, 2012, p. 1) to use economic and management approaches for enhance productivity:

- Economic approach is aimed at modernization of production, optimization of production processes, reducing the cost of labour (working time) on production of a unit of production and (or) issuance of additional production quantity per unit of time, etc.

- Management approach aimed at increasing the involvement of the staff, orientation members for effective and productive work. One of the significant factors affecting the increase of the level of employee engagement, is a well-functioning system of remuneration.

The author of this work offers take into account the factors of production and human resources equally. And we don't know which one to give preference in practical work.

Let's look at the causes of low productivity are listed in the work (hw4, pp. 1-2):

- bloated the administrative apparatus;

- bloated staff;

- a large number of control, inspection services;

- ill-conceived management decisions;

- poor work organization.

These reasons relate to the economic approach. Their elimination is aimed at reducing the cost of labor (working time) to produce a unit of output (Yandex.Direkt, Sposoby povyshenija proizvoditel'nosti truda/ Konsul'tant, 2012, p. 1). 
Okulich-Kazarin V. Some techniques for intangible incentives employees

MEST Journal Vol. 2 No. 2 pp. 181-191

Enumeration of these reasons does not explain what approach is better: economic or managerial?

G. Gorin published an interesting thought answering this question. He in the (Gorin, 2006) explained that the system of personnel motivation cannot be called effective if it is based on the action of the material factors (such as salary, premiums, and bonuses) only. We think this idea is very good. Because it does not require significant capital and financial investments.

In paper (Yandex.Direkt, Motivatsiya personala, 2012) provides a detailed description of the methods of motivation. There are several theories of motivation (Abraham Harold Maslow, David Clarence McClelland, Frederick Irving Herzberg, Victor Vroom, Douglas McGregor and others). The theory is considered in (Yandex.Direkt, Motivatsiya personala, 2012) do not exhaust the full list of the theories of motivation.

From a practical point of view, the causes passivity and low return of workers are given in (Yandex.Direkt, Motivatsiya personala, 2012, p. 14):

- excessive intervention by the chief;

- the lack of psychological and organizational support;

- lack of necessary information;

- the lack of attention of the head to the needs of a subordinate;

- the absence of feedback, that is, the ignorance of the worker of the results of their work;

- inefficient decision of the head office of the problems of the employee;

- incorrect estimation of the employee's supervisor.

Economic and managerial approaches are combined in this list of reasons for low productivity.

Three systems are available for elimination of these reasons:

- the system of direct tangible incentives (Yandex.Direkt, Motivatsiya personala, 2012, p. 19);

- the system of indirect tangible incentives (Yandex.Direkt, Motivatsiya personala, 2012, p. 20);

- the system of intangible incentives (Yandex.Direkt, Motivatsiya personala, 2012, p. 22).

Author of (Kak povysit' proizvoditel'nost, 2013, p. 1) considers the methods of non-material motivation and recommends the strengthening of labour discipline; improving working conditions; sensitivity management personnel; the inclusion of workers in the program of complex quality management and using of flexible working time for a given groups of employees.

The specialists of the company Pricewaterhouse Coopers formed a system of intangible incentives on (Yandex.Direkt, Motivatsiya personala, 2012, p. 32). They developed a classification of forms of intangible incentives also. Two parameters were assumed as a basis of this classification. It is the volume of expenses for organization of stimulation and value of the methods for employees. The matrix can serve as a map to choose the tools intangible rewards based on the needs of a specific company (Yandex.Direkt, Motivatsiya personala, 2012, p. 33).

In paper (Yandex.Direkt, Motivatsiya personala, 2012) the regularities identified in accordance with different motivation theories (A. Maslow, D. McClelland, F. Herzberg, L. Porter, E. Lawler etc).

First, physiological needs come first. There are clean air, water, food, warmth, the need for security and stability updates.

Next, the spiritual needs are. These needs are in a meaningful reference group and in a social relationships.

Third, the need for recognition, prestige and respect are.

And finally, the need for self-expression completes the chain needs.

The main types of motivation proposed in (Yandex.Direkt, Motivatsiya personala, 2012, p. 41) based on the above needs.

In Russia much research in recent years has focused on methods of tangible incentives. Here we refused to consider methods of tangible incentives specifically. Our reason for refusal is the results of a new study (Shatova, 2014). 
A latest paper (Shatova, 2014, p. 1) showed that $40 \%$ of employees in Russia are not motivated. This study made by the Hay Group. The company Hay Group examines the efficiency of the staff in the different countries of the world regularly. In Russia the study is based on data obtained from more than 60 Russian companies from various industries. This Study covers more than 140 thousand employees.

The survey results clearly indicate that for Russian companies it is critical that managers have invested more time and effort in contact with staff (Shatova, 2014, p. 2). Expected results of such contacts is to support employee motivation.

Because of these findings we hypothesize that 2 powerful methods of tangible incentives of the proposed list (Yandex.Direkt, Motivatsiya personala, 2012, pp. 42-43) should be used.

\subsection{Metodology}

Two powerful techniques of intangible incentives were obtained by studying the experience and making the experiment. Our key research technique is to analyze some scientific sources and the behavior of a person under different terms of motivation. We used well-documented and powerful methods of analysis. All of our methods were economically justified.

While the exact methodologies used vary from field to field, the overall process is the same. First, we define the question - what exactly we are trying to find out. We use the scientific method to search for relationships between tangible and intangible incentives. In general we learn from 50 to 100 scientific sources on an interesting topic. After that we choose the hot ones for a detailed analysis. We welcome alternative and nontraditional positions of researchers.

Next comes the formation of a hypothesis, which is an idea or explanation for a situation based on what is currently known.

The next stage of the method is the design of an experiment which will allow this hypothesis to be tested. Usually a primary run of the experiment is conducted, and any changes to the experimental conditions made. Experiments are designed so that one or two variables are changed. And the effects of the change observed. In each experimental run data collection takes place, followed by data analysis.

Finally the data is interpreted and from this, we are able to draw conclusions. And we create a new powerful methods of motivation on the basis of theoretical analysis and best practices.

The starting point for further analysis remain assumptions published in (Yandex.Direkt, Motivatsiya personala, 2012). One of the main ideas of this publication suggests that intangible incentives is a good supplement to the intangible one. The company must provide the workers with the market average salary and comfortable working conditions (Yandex.Direkt, Motivatsiya personala, 2012, p. 29). It is certainly hard to see a plausible alternative to this idea still if we look from other points of view [(Lapusta, 2001) (Vesnin, 2001) (Vesnin, Upravlenie personalom v shemah: ucheb. posobie, 2014)].

First, M.G. Lapusta and his colleagues were quite right when he said that salary is a form of economic realization of the right of employees to its resource work (Lapusta, 2001).

Second, in 2014 V.R. Vesnin (2014) have defined the purpose of stimulation is not encourage to work. The aim of motivation is to get to do more and better than it is provided by the standard tasks.

Third, studies (Vesnin, 2001) shown that usually motivations of people who want to work are the following:

- firstly, $45 \%$ prefer the glory,

- secondly, $35 \%$ prefer satisfaction with the content of the work,

- $\quad$ thirdly, $8 \%$ prefer the power.

- and finally, the rest $12 \%$ has money as the main motive of work only!!!

In other words the methods of intangible incentives are important for $88 \%$ of employees. It is a reason why tangible incentives cannot ensure high productivity. Do you remember that $40 \%$ of employees in Russia are not motivated (Shatova, 2014, p. 1)?

These results [(Shatova, 2014) (Lapusta, 2001) (Vesnin, 2001) (Vesnin, Upravlenie personalom v 
shemah: ucheb. posobie, 2014)] allow us to take an alternative view. We assumed that the main incentives are intangible factors. We believe that the company burn money, if based on the tangible methods of personnel motivation only.

That is why we carefully considered the list of methods of non-monetary motivation (Yandex.Direkt, Motivatsiya personala, 2012, pp. 42-43). And we chose 2 powerful methods of intangible incentives should be used by companies. These 2 techniques will be strengthened further:

1. competition,

2. training.

Let us consider first the powerful techniques of intangible incentives called "competition".

\subsection{Competition}

\subsubsection{Case 1}

In February 2014, we started the competition at our University. 34 students participated in the experiment. First-year students of speciality "management" were selected. They study the subject of "Organizational behavior". And they pass the control of academic results each month. The boundaries of the scale of academic results is applied from 0 to 10 .

What changes we made? We just warned students that apply competition (ranking) for the results of each test. And we said that the results will be compared with each other.

Previously we just had a control test. And we announced assessment to students. Now we've started to compare different academic results of the students.

For the first time the results of the control test were included in the competition (rating) in March 18, 2014. The average score for the group of students was 5.35 units. Our supervision showed a high interest of the students to their place in the group. Some students asked to rewrite test. Repeat the test results were not taken into account in our experiment.
April 15, 2014 rating (competition) was drawn up for the second time. The average result for the group of students was 6.86 units.

As a result, the growth of the educational results within 1 month was 1.51 units (from 5.35 to 6.86). This is $28.22 \%$.

Growth of the educational results to $28.22 \%$ was not required expenditures of money or other resources. We have provided students with access to the results of the rating. Each student wanted to take a higher place. And they worked with more efficiency. In other words, the desire of students to win in the ranking was the main resource of motivation.

Expenditure of financial and other resources is no.

Because we have experience of running of competition in the form of ranking, we expected the growth of the educational results.

\subsubsection{Case 2}

Some years ago one of us organized a competition (rating) in the Krasnodar region (Russia). The purpose of the administration of Krasnodar region was to improve the productivity of research work in the region. The aim of the rating was to increase the share of young scientists in the age structure of the scientific and pedagogical staff. Therefore, the rating was organized for the leading researchers of the Krasnodar territory.

Five criteria were selected for the rating by method statistics: the total number of publications (A1); the number of scientific publications (A2); the number of international publications (A3); the number of innovations used in the Krasnodar region (A4); the number of $\mathrm{PhD}$-thesis defense, which was led by scientist (A5).

A computer program to evaluate the effectiveness of scientific work was made. As we receive it?

First, we have collected statistical data on eight criteria. Then we drew a statistical graphs for each of the analyzed criterion. A fragment of the graph $R=f(A 1)$ is shown in Fig. 1 


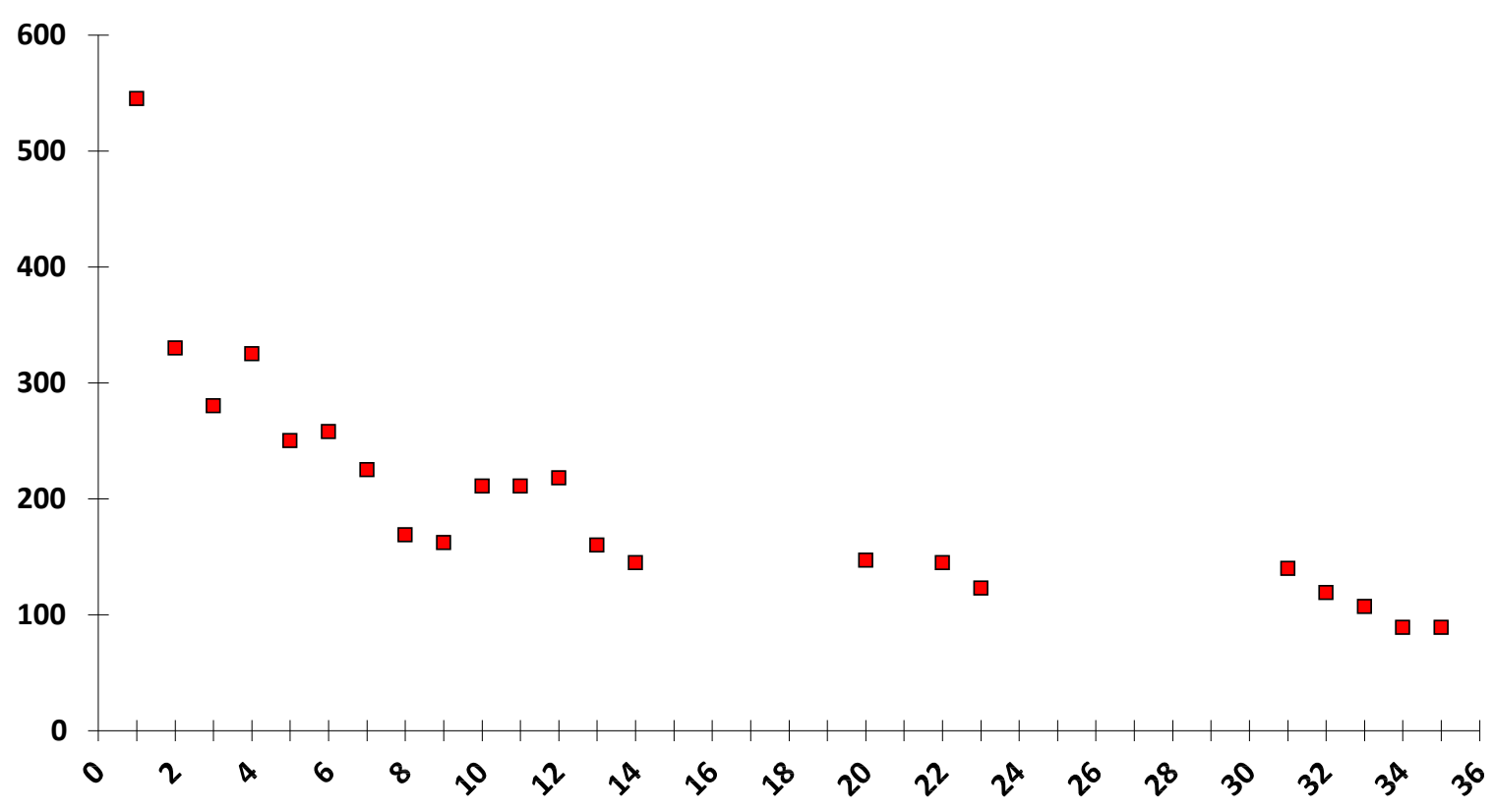

.Fig.1 Total number of publications $(Y)$ and place in the rating of $(X)$

At last, the empirical formula for the calculation of the rating of researchers was withdrawn by the regression analysis. All estimated coefficients were inspected by the Student's criterion. 3 criterias we removed after the inspection.

You can see that the coefficient for the PhD-thesis defense was the most high:

$\mathbf{R}=0,13 \times(\mathrm{A} 1+\mathrm{A} 2)+0,96 \times \mathrm{A} 3+1,38 \times \mathrm{A} 4+3,17 \times \mathrm{A} 5$

The correlation coefficient was $\mathrm{R}=0.983$.

The sum of points was used to assess the effectiveness of the work of scientists. The results of calculations were placed by the computer program in decreasing order of the score. The administration of Krasnodar region awarded the winners of the rating by honorary badge.

The increase in the number of young scientists was:

- for the first year from 436 to 610 people, that is $\sim 40 \%$;

- for the second year from 610 to 732 people, that is $~ 20 \%$;

- for the third year from 732 to 896 people, that is $\sim 20 \%$.
As a result, the number of young scientists grown in $\sim 2$ times in the Krasnodar region for 3 years (from 436 to 896 people).

We did not make large investments. 2 times a year we collected reports on the results of scientific work of leading scientists. We treated them according to the elaborated computer program and published in the open press. Several of the winners of the rating were awarded by honorary badge of the Governor of Krasnodar region.

Expenditure of financial and other resources are close to zero.

\subsubsection{Competition: theory and practice}

Nothing can detract from the central fact that the competition is useful for each company. However what is even more surprising is that the competition is useful for every employee.

We would say that the following statement is itself sufficient to explain the usefulness of the application of competition for managers and businessmen. "The spirit of costatellus is innate quality of any child. And the attraction of risk and mercantile interests appear as the child is growing and gaining experience", - stated in (Vajke, 1994). Experiences competing give a splash of deep human emotions and sexual needs (Okulich- 
Kazarin \& Sadykova, 2007, p. 9). It is an unconscious desire to meet the psycho-biological needs directs the participants of the competition. Amazingly, but the power of the desire to competition may not depend on the magnitude of financial gain or financial loss (Vajke, 1994).

Please be attention: the reality is that man seeks to competition always and everywhere [(Vajke, 1994), (Okulich-Kazarin \& Sadykova, 2007, p. 9)]. If the employee does not compete on the job, he will compete outside of work. People will spend their energy, playing sports and gambling. Look how many people play computer games and play in the casino! People could devote the competition at work this energy, this emotion, this time. People earn money, competing at work. People spend money, competing outside of work.

Responsibility of managers and businessmen is to organize a competition at work.

Responsibility of managers and businessmen is to save people from unknowingly losing money.

Responsibility of managers and business owners is to enable people to earn money.

If managers and businessmen do not use the competition, they burn the money.

The atmosphere of competition in the company stimulates I-status of "Child" to the manifestation of a spontaneous activity and creativity (Bern, 1992). Competition stimulates development of creative activity, initiative, innovation and responsibility [(Samygin, 1998), (Slastenin, Isaev, Mishhenko, \& et al, 2000)]. Involvement of employees in the struggle to achieve the best results raises behind to the advanced level.

It doesn't matter how many criteria you use when organizing competitions. We have proved that benefit to the company will bring any number of criteria. Choose economically reasonable number of criteria for the rating.

Maintaining a high level of motivation is achieved by summarizing competition 12-15 times a year (Shherbakov, 1996).

Also we use "short" competition in the classroom. "Short" competition is a competition within 15-30 minutes. Description of the methods of holding "short" competition is beyond the scope of this paper.

\subsection{Training}

\subsubsection{Case 3}

Recently we carried out the order of the Moscow data center of Russian Railways. The purpose of the order was to increase a labour productivity of managers. The goal is achieved through training 40 managers. Two groups of 20 people were formed. They are trained by the training of a new generation. Each group was intensively studied for 18 hours.

The average growth of personal competences amounted to 40 managers:

- focus on results - 63\%;

- attentiveness - 60\%;

- leadership - 16\%;

- creativity - 420\%;

- logical thinking - 66\%.

The average growth of managerial competencies amounted to 40 managers:

- $\quad$ the ability to work according to plan - $57 \%$;

- $\quad$ the ability to allocate the main thing - $82 \%$;

- $\quad$ tasks to the deadline - 57\%;

- $\quad$ find the information they need - $96 \%$.

The economic results are the following:

- the purpose of the order was achieved as the speed and quality of work of managers grew by $57-96 \%$,

- comprehensive approach to the development of managerial skills and competencies brought additional 180 man-days,

- saving of budget staff development amounted to $\$ 30,500$ through the use of new patented technologies of training managers.

Below we will talk briefly about the use of new patented technologies of training managers.

\subsubsection{How our training helps to improve incentives to work?}

When companies hire employees, they mostly are interested in their competencies. Companies are not interested in their attitude to work. However, attitude to labor determines the level of intrinsic motivation. In turn, the motivation is a major influence on the desire of the employee to learn 
and to quality work. The company's easier to teach a motivated employee than motivate qualified specialist (Yandex.Direkt, Motivatsiya personala, 2012, p. 40). Therefore it is better to hire people who demonstrated a high level of motivation to work, optimism, enthusiasm and desire for growth.

In our case, the employees were highly qualified and had weak internal motivation to work. It is quite true that this situation is not so rare than managers and businessmen want.

During the training we developed the key competences which affect the internal motivation to work. Some methodological conditions for the studies borrowed from work (Okulich-Kazarin, 2013, p. 115).

High unconscious internal incentives to work is formed by the high level of these competencies: focus on results, leadership, and ability to work according to plan, and tasks to the deadline.

In turn, high internal incentives to work ensures high productivity of employees.

\section{CONCLUSIONS}

We learned advanced methods of intangible incentives of employees. And we found that the methods of intangible incentives are important for $88 \%$ of employees. Our experiment has confirmed this observation. Managers and businessmen can reduce the cost of motivation if they will apply the intangible incentives.
Two powerful methods of intangible incentives were suggest for using. They can be useful for companies seeking to raise labor productivity of employees:

1. Competition is strong and fast reception of productivity. It is not important what criteria will compete employees. Competition helps to direct more energy to profit growth. Our experiments showed an increasing employees activity to $20-40 \%$.

2. The second major of intangible incentives is training. Each company has to spend money on training their staff in new technologies. The good news is that the new generation training combines professional growth and growth of internal motivation. Staff can work better, harder and faster on $57-96 \%$ after combined training. Business owners and managers will receive a great savings if they will train the staff on the new generation training.

The results of our research are applied in the practice of Russian and other companies. Managers and businessmen will rejoice in the results of work of employees. The success of their Companies will good when they can implement competition and the new generation training.

Our results is very important in the beginning of a new world crisis.

The next step in our research will be the design of a motivational "ladder" for intangible incentives of employees.

\section{WORKS CITED}

Bern, E. (1992). Igry, v kotorye igrajut ljudi. Psihologija chelovecheskih vzaimootnoshenij; Ljudi, kotorye igrajut v igry. Psihologija chelovecheskoj sud'by. Lenizdat.

Center-YF. (2012, 09 04). Proizvoditel'nost' truda. Retrieved from Center-YF.ru: http://www.centeryf.ru/data/economy/Proizvoditelnost-truda.php

Cvetkov, A. (2008). Menedzhment. Retrieved from vse-uchebniki.com: http://vse-uchebniki.com/teoriyaupravleniya-besplatno/shkola-nauchnogo-upravleniya-teylor-ego-22560.html

Davenport, T. (2011). Zarabatyvaja umom. Kak povysit' proizvoditel'nost' i uluchshit' rezul'taty dejatel'nosti rabotnikov intellektual'nogo truda. Moskva: Olimp-Biznes.

Gorin, G. (2006). Kak s pomoshh'ju nematerial'noj motivacii dobit'sja vysochajshej proizvoditel'nosti personala. General'nyj Direktor(11).

hw4. (n.d.). Kak povysit' proizvoditel'nost' truda. Retrieved from hw4.ru: http://hw4.ru/m-productivity 
Okulich-Kazarin V. Some techniques for intangible incentives employees

MEST Journal Vol. 2 No. 2 pp. 181-191

L, N. (2013, 01 28). Kak povysit' proizvoditel'nost. Retrieved from Znaniya.com: http://znanija.com/task/1340987

Lapusta, M. (Ed.). (2001). Spravochnik direktora predprijatija (5th ed.). Moskva: Infra-M.

Okulich-Kazarin, V. (2013). How to win a low productivity of a post-Soviet economy. International Congress «Modern tools of Economics. New alternatives»,, (pp. 113-116). Vienna, Austria.

Okulich-Kazarin, V., \& Sadykova, D. (2007). Teoreticheskie osnovy igrotehniki: Uchebnometodicheskoe posobie. Moskva: Di-graf.

Samygin, S. (Ed.). (1998). Pedagogika i psihologija vysshej shkoly (Uchebniki, uchebnye posobija ed.). Rostov-na-Donu: Feniks.

Shatova, J. (2014, 03 18). 40\% sotrudnikov v Rossii ne motivirovany. Chto delat'? Retrieved from hrm.ru: http://hrm.ru/blog_40-sotrudnikov-v-rossii-ne-motivirovany-chto-delat_14BC56

Shherbakov, J. (1996). Psihologija dlja prepodavatelja (Ucheb. posobie dlja slushatelej fakul'teta povyshenija kvalifikacii i aspirantov ed.). Krasnodar: KubGTU.

Slastenin, V., Isaev, I., Mishhenko, A., \& et al. (2000). Pedagogika: Uchebnoe posobie dlja studentov pedagogicheskih uchebnyh zavedenij (3rd ed.). Moskva: Shkola-Press.

Smirnov, S. L. (2011). Hotite povysit' proizvoditel'nost' truda i pribyl' Vashego predprijatija bez investicij? Retrieved from trudexpert.pro: http://trudexpert.pro/vy-xotite-povysit-proizvoditelnost-truda-ipribyl-vashego-predpriyatiya-bez-investicij/

Vajke, A. (1994). Jenciklopedija azartnyh igr. Moskva: Efrat.

Vesnin, V. (2001). Prakticheskij menedzhment personala: Posobie po kadrovoj rabote. Moskva: Jurist".

Vesnin, V. (2014). Upravlenie personalom v shemah: ucheb. posobie. Moskva: Prospekt.

Yandex.Direkt. (2012, 09 06). Motivatsiya personala. Retrieved from Center-YF: http://www.centeryf.ru/data/ip/Motivaciya-personala.php

Yandex.Direkt. (2012, 10 04). Sposoby povyshenija proizvoditel'nosti truda/ Konsul'tant. Retrieved from Delovoy Mir: http://delovoymir.biz/2012/10/04/sposoby-povysheniya-proizvoditelnostitruda.html

Received for publication: $\quad 02.02 .2014$

Revision received: $\quad 07.06 .2014$

Accepted for publication: $\quad 23.06 .2014$

\section{How to cite this article?}

Style - APA Sixth Edition

Okulich-Kazarin, V., Prichina, O., \& Stecenko, I. (2014, 07 15). Some powerful techniques for intangible incentives employees. (Z. Čekerevac, Ed.) MEST Journal, 2(2), 181-191.

doi:10.12709/mest.02.02.02.19

\section{Style - Chicago Fifteenth Edition:}

Okulich-Kazarin, Valeriy, Olga Prichina, and Irina Stecenko. 2014. "Some powerful techniques for intangible incentives employees." Edited by Zoran Čekerevac. MEST Journal (MESTE) 2 (2): 181-191.doi:10.12709/mest.02.02.02.19. 
Style - GOST Name Sort:

Okulich-Kazarin Valeriy, Prichina Olga and Stecenko Irina Some powerful techniques for intangible incentives employees [Journal] // MEST Journal / ed. Čekerevac Zoran. - Belgrade : MESTE, 07 15, 2014. - 2 : Vol. 2. - pp. 181-191.

Style - Harvard Anglia:

Okulich-Kazarin, V., Prichina, O. \& Stecenko, I., 2014. Some powerful techniques for intangible incentives employees. MEST Journal, 15 07, 2(2), pp. 181-191.

Style - ISO 690 Numerical Reference:

Some powerful techniques for intangible incentives employees. Okulich-Kazarin, Valeriy, Prichina, Olga and Stecenko, Irina. [ed.] Zoran Čekerevac. 2, Belgrade : MESTE, 07 15, 2014, MEST Journal, Vol. 2, pp. 181-191. 